\title{
Agribusiness as a veritable tool for rural development in Nigeria
}

\author{
Pawa Tersoo \\ Department of Political Science, College of Education, Katsina-Ala, Benue State, Nigeria \\ Phone: 08066745423 \\ E-mail address: terspawa@gmail.com
}

\begin{abstract}
This paper examines the role of agribusiness in all its tri-aggregates to the socio-economic development of the rural sector in Nigeria. It acknowledges the importance of agriculture as it employs a majority of the rural population in a predominantly agrarian society like Nigeria. It draws majorly from documentary evidence on agribusiness and agro-industrial linkage and reveals that, the farm, off farm and processing components of agribusiness are capable of generating jobs, provision of income, poverty reduction and infrastructural growth. The paper however identifies poor policy articulations, shortage of working capital, poor infrastructure lack of ideology etc. as major obstacles to effective agribusiness. The paper recommends a robust political will, a sound ideological frame, adequate funds among other measures to develop a strong interface between agricultural policies and politics in achieving a sustainable agribusiness as a veritable tool for rural development in Nigeria.
\end{abstract}

Keywords: Agriculture; Agro-industry; Agribusiness; Rural development

\section{INTRODUCTION}

The role of agriculture in a growing economy where majority of the poor employed by this sector are located in the rural areas cannot be underestimated. Agriculture and industry occupy very strategic positions in the development process of the Nigerian economy. This is because industrialization is assigned a leading role in the development of an economy like ours. This is in terms of its provision of employment and income; diversification of the economy and export, improvement of balance of payment; diffusion of technical and managerial skills in an agrarian economy like ours, this can only be feasible with the impetus and complementary role of the agricultural sector.

On the other hand, agriculture which is the dominant sector of a developing economy employs two third of the poor located in the rural sector. It therefore needs a boost towards rapid development and productivity in a linkage with the industry. The symbiotic link between these two sectors is born out of the desire to foist an integrated production structure, thereby employing the surplus labour from agriculture as well as creation of backward integration and forward linkages. The position of agriculture as a catalyst to industrialization produces a synergy derived from the agro-industrial theory which emphasizes congruence between agriculture and industry. This theory identifies three major contributions of agriculture in industrialization which include: increased production of food, supply of raw materials and 
provision of capital flow and expanded market for the manufacturing industry. These are couched in "factor", "production" and "market" contributions (Meier, 1976, Dunmoye, 1978,).

The centrality of agribusiness in the interface between agriculture, and the rural sector cannot be easily waved aside. This is because; agribusiness has the capacity to provide greater employment, higher incomes, poverty reduction and provision of Corporate Social Responsibility (CSR) via their requisite infrastructure. It does provide inputs to farmers and connects them to the consumers via general handling, processing, transport, marketing, and distribution of agricultural products. The synergy between agribusiness and agro-industrial linkage (commercial activities) is a great potential for development of the poor rural majority in Nigeria. Despite their importance in the development process, the sectors face a myriad of problems, ranging from the vicissitudes of nature to the bizarre vagaries of political inconsistencies and discontinuities. (Dike, 1991, Anyanwu, 1997, Dunmoye, 1997).

On a particular note, Sullivan and Ikpeze (1980:152) have argued that: "the most prominent of these difficulties are inavailability of financial capital, lack of entrepreneurship, management ability and technology; inadequate socio-economic infrastructure; uneven spatial development, participation by foreigners in industrialization process and the spatial problem of small scale industry".

In order to overcome these problems, agribusiness becomes a feasible strategy for rural development considering these contending grounds:

(i) Agriculture employs a greater proportion of the Nigerian population.

(ii) Agriculture has the potentials for the impetus to stimulate industrialization and economic development through factor, market and product contributions.

(iii) Agribusiness is a development imperative hence a strategy that places majority of Nigerians at the centre as the means and end of development.

Ellis (2010) presents this similar orthodoxy on Sub-Saharan Africa that: Most of poor in Africa live in rural areas but why poverty rate is high is due to Africa's failure to replicate the Asian Green Revolution.

Securing strong yield agriculture is believed to be capable of generating higher incomes for the small farm households; when these incomes are used on locally produced products it can generate cumulative spirals of increased rural activity; consequently, this is successful within the ambit of agribusiness. Consequently, the Nigerian government has over the years pursued several agricultural and rural development policies in a bid to reconstruct a self-reliant nation and a dynamic economy.

These include: National Accelerated Food Production Programme (NAFPP), River Basin Development Authorities (RBDAs), Agricultural Development Programme (ADPs), Operation Feed the Nation (OFN), Green Revolution (G.R), Directorate of Food Roads and Infrastructure (DFRRI) etc.

Nevertheless no policy was articulated to promote agribusiness neither was there any separate policies for rural development. As such none of these policies made a far reaching impact on the rural man. 


\section{THEORETICAL FRAMEWORK}

The Marxian Political Economy (MPE) suitably explains the subject matter of our discourse here. In its materialistic interpretation of history, the whole state (society) is divided into the superstructure (politics religion culture jurisprudence) and the economic system or mode of production which is the dynamic interaction of productive forces and their corresponding relations of production (Onimodi 1985). Productive forces are the unity of objects (raw materials) and instruments (implements) of labour plus (physical) labour power. MPE argues that an economic system can only change with advancement or development (the capacity) of productive forces which creates a conflict between (owners/non-owners of the means of production) relations of production leading to a new arrangement in the interaction between the advanced productive forces and the new relations of production. Consequently, a new society emerges in correspondence with the new economic determinism and with new patterns of economic activities.

The application of dialectical changes on the existing agrarian system towards a predominantly commercial one via agribusiness is actually a new framework for an emerging agro-industrial sector from the dynamic link between the farm and nonfarm components. Since the rural sector employs a greater labour in Nigeria, an emerging sector from the rural agrarian system will actually be a social reality. From this line of argument, agribusiness is considered a factor in the development of productive forces of the present mode to a higher one hence a veritable tool for rural development.

\section{CONCEPTUALIZATION}

The concept of agribusiness linked, rural development and agro-industry are key concepts that must be explained here.

Agro-Industry:

An agro industry is one which specializes in processing of agricultural products. Agroindustrialization is a dynamic integrated production process and a synergy or symbioses between agriculture and industry. This new sector directly interfaces with both agriculture and industry and thereby provides a link between the two sectors making them more contributory to economic development. This is the main thrust of Lewis two sector-model. There are therefore backward integrations and forward linkages, emanating from this synergy that engenders agribusiness as a potential for rural development. Through this sector supplies, processing and distribution of products involves large scale production, processing and packaging of such agricultural products using modern technology.

\section{AGRIBUSINESS}

Agribusiness is a concept that became popular in the early sixties. It arose along with recognition of the agro-processing sector as new an emerging sector. According to Davis (1956), agribusiness is the sum total of all the operations involved in the manufacture and distribution of farm supplies, production operations on the farm and the strong processingdistribution of commodities and items. Davis and Goldberg (1957), view agribusiness as dividing the structural components of the production process into substructures which are 
capable of being administered integratively. Three substructures of this sector are the input; farm productions and the marketing section for processed products. This concept implies the process by which corporate firms supply agricultural inputs or purchase farm outputs and process them for onward distribution in an integrated pattern. Agribusiness is grouped into three primary tri-aggregates: (i) farm supply (ii) farm production (iii) processing distribution.

From the foregoing, it can be juxtaposed that, there is a synergy in the agribusiness - rural development nexus through inputs supplies, processing and distribution that that characterize its development. On the other hand, agribusiness provides the much employment and food for the abundant rural labour force, expands the market, increases the incomes of those involved in the supply components processing and distribution of agro-industrial products. The intrinsic value of agribusiness is that, it constitutes a synergy of agro-industrial linkage and in the nutshell, involved in the production and distribution of food and fiber needs of the economy. It therefore generates backward integration and forward linkages, thereby facilitating the release of workers from the farm to other sections of the tri-aggregates. This synergy is an interesting option for industrialization. Such a process is expected to transform agriculture and at the same time create new industrial jobs and incomes.

According to Olayida and Heady (1982), the farm supply and production components are very important but they depend on such infrastructural facilities like land, labour capability, water and management. The nature and character of agribusiness can best be assessed by the kind of synergies that exist between agriculture, and the non-farm sector. From the FLO (2007) and WDR (2008) have it that recent trends have shown a rapid increase in the production value adding chain through agribusiness related opportunities which impact greatly on poverty alleviation because it is expected that, agribusiness can spur agricultural growth thereby engendering a strong link with the smallholders that can consequently reduce rural poverty.

The value chain obtained from agribusiness opportunities is that, as the demand and market for agro-processing products increase, the supply enterprises component of the triaggregates furnishes the farm sector inputs and services consequently: Inducing productivity, quality improvements and market innovation. In this situation the agribusiness/agriculture ratio captures (a) the degree of productive and commercial development of agro-related activities (b) the sophistication of agro-industrial backward and forward linkages, the capacity or level of value adding market creation and the importance of distribution and retailing.

In agrarian countries, a higher agribusiness/ratio holds a capacity for diversification and socio-economic development as Da Silva et al (2009:49) have rightly observed that; "... moving the core economic activities from the farm gate to the agro-industrial sector and its services may represent productive diversification and lead to higher levels of productivity and income generation as well as higher shares of non-farm employment in rural areas." This scenario is made feasible with a dynamic link between the farm sector; rural industries and all associated activities.

\section{AGRIBUSINESS IN NIGERIA}

According to Marchet et al (2001), Agribusiness concerns in Nigeria constitute $70 \%$ of businesses operating in the country. In a survey, NISER (1999) observed that 41 percent of agro industries are sole proprietorships, while another 41 percent are private limited liability companies. About 4 percent are government owned, and 5 percent are of partnership nature while 8 percent are public liability companies. In Nigeria agribusiness can be divided into four 
components; farming inputs supply companies; producing farm firms, processing agribusiness firms and food marketing and distribution.

(a) Farm Input Supply Business: This encompasses agricultural chemical inputs suppliers of fuels, fertilizers, pesticides and herbicides seed and feed concentrate suppliers; agricultural machinery and equipment suppliers; automobile, tube, tires, and foam manufacturers; credit and veterinary services suppliers. This supply component extends to supplies of containers, sacks, crates needed in the packaging activities. Quite important as well are utilities like water, power, telephone, hospital insurance etc.

(b) The Producing Farm Firms: These are crop producers and livestock producers who are farmers scattered all over the country. The growth of this component depends on available large land, improved productive forces and complementarity with industry that absorbs excess agricultural labour.

(c) Food Processing Agribusiness: This includes food and fruit juice canners; manufacturers of beer, soft drinks, cocoa drinks, coffee, and tea; producers of confectionary sugar sweets, chocolate, cakes, biscuits; tobacco processors and/or manufacturers; meat processors; wood processors and furniture makers and distributors, paper millers and tissue paper manufacturers; leather and footwear manufacturers; food packaging and cartons manufacturers; cotton processing, spinning, weaving and textile companies; food processors of cornflakes, jam, bread, butter, milk, margarine, and tomato puree; oils, soap, and toothpaste manufacturers, fishing companies, fish processors, packers and distributors.

(d) The Food Marketing and Distribution Agribusiness: Companies in the country include private food stores; wholesalers and retailers of frozen foods including super markets etc.

These agribusiness firms are scattered all over the country but are concentrated in three main industrial clusters in Nigeria; Kano, Kaduna, Jos in the north; Lagos, Otta Ibadan in the south west and Port Harcourt, Aba, Nnewi, Onitsha in the southeast. A survey of a few include: Taraku Oil Mills Ltd, Abakiliki Rice Processors, Sorghum Outgrower Scheme with Guinnes Plc, Fuman Agric Agricultural Products Fruit Juice Manufacturers and Cocoa Exporter Ed and F man Nigeria etc.

\section{RURAL DEVELOPMENT}

There is no consensus definition of rural development as a (strategy or outcome) a means or an end. According to Conference on Regional Planning and Economic Development in Africa (1972:19) means, "the outcome of series of quantitative changes occurring among a given rural population and whose conveying effects indicate, in time, a rise in the standard of living and favourable changes in the way of life of the people concerned". Lele (1975) and Alakare (1977) view rural development as the improvement in the living standard of the rural dwellers by engaging them in productivity activities such as establishment of rural industries that will increase their income.

This is the only means of raising sustainable level of the rural poor by giving them the opportunity to develop their full potentials. Mabogunje (1981) adds that meaningful rural development must be on "self-sustaining basis, through transforming the socio-spatial structures of the productive activities..." (Olayiwola and Adeleye (2005). 
As a means on the other hand, the World Bank (1977) defines it as "a strategy designed to improve the economic and social life of a specific group - the rural poor". The United Nations (1978) cited in Ukwu, (1995: ) defines it as: "A strategy designed to transform rural life by extending to the masses of the rural population the benefits of economic and social progress, it stresses fundamental principle: process through equitable access to resources, imputes and services and participation in the design and implementation programmes." In his view, Diejemach, (cited in Ijere, 1992) argues that, rural development is a process of not only increasing the level of per capital income in the rural areas but also the standard of living of the rural people, depending on such factors as food, (nutrition) level, health, education, housing, recreation and security. Similarly, this socio-economic development approach is simplified by Jir (1995:84) where he explained rural development to mean; "the improvement of living conditions in rural areas through increased productivity of agriculture and related enterprises which constitute the main economic activities of the population". Towards achieving this, he emphasizes the centrality of inter-sectoral linkages where he argues that:

The rural economy of the country has also been largely hampered by the absence of an effective methodology for integrating agriculture, which is the main economic activity with the other sectors (industry and services) and also with many other factors affecting rural life. The simultaneous planning of the three sectors - agriculture, industry and services - at the level where development activities take place is one sure way to attain complementarity. This is a multi-dimensional and comprehensive approach, the strength of which lies in the achievement of inter-sectoral linkages.

In a nutshell rural development is concerned with raising the quality of life of low income rural majority on a self-sustaining basis through a fundamental transformation of the rural mode of production (NRSA, 1987).

This means rural development must be clearly designed to increase production of the poor and their ability to contribute for the national economy. Towards achieving this change of mode of production, the Directorate of FRRI perceived it to be:

(a) To improve the quality of life and standard of living of the majority of the people in the rural areas by:

(i) Substantially improving the quality, value and nutritional balance of their food intake;

(ii) Raising the quality of rural housing as well as the general living and working environment in the rural areas;

(iii) Improving the health conditions of the rural population;

(iv) Creating greater opportunities for employment and human development;

(v) Making it possible to have a progressively wider range and variety of goods and services to be produced and consumed by the rural people themselves as well as for exchange.

(b) To use the enormous resources of the rural areas to lay a solid foundation for the security, socio-cultural, political and economic growth and development of the nation.

(c) To make rural areas more productive and less vulnerable to natural hazards, poverty and exploitation, and to give them a mutually beneficial linkage with other parts of the national economy.

(d) To ensure a deeply rooted and self-sustaining development process based on effectively mobilized mass participation. 


\section{AGRIBUSINESS FRAMEWORK FOR RURAL DEVELOPMENT}

In their position, Olayida, Ogunfowora, Essang and Idachaba (1981) argue that agroindustrial linkage constitutes a strategy that appreciates the role of agro-industrialization in the development process of an economy as: stimulating transition to a modernized economy; optimal utilization of scarce resources; engendering complimentarity between small holders and large production units; increasing non-farm employment opportunities and achievement of geographical decentralization of industry and long industrial conurbations. The viability of this framework depends on the capacity of the economy to sustain agribusiness itself via a dynamic complimentarity between the farm and non-farm components which have the potentials for the realization of this framework.

The basis of this framework is justified by Todaro and Smith (2011:452) where they argue that:

Rural development, though dependent primarily on small-farmer agricultural progress, implies much more. It encompasses (a) efforts to raise both farm and nonfarm rural real incomes through job creation, rural industrialization, and other nonfarm opportunities and the increased provision of education, health and nutrition, housing and a variety of related social and welfare services; (b) a decreasing inequality in the distribution of rural incomes and a lessening of urban-rural imbalances in incomes and economic opportunities; (c) successful attention to the need for environmental sustainability - limiting the extension of farmland into remaining forests and other fragile areas, promoting conservation, and preventing the harmful misuse of agrochemicals and other inputs; and (d) the capacity of the rural sector to sustain and accelerate the pace of these improvements over time.

Given the value chain process via employment, income, markets and poverty reduction from agribusiness the rural sector can attain sustainable growth from the raising farm-nonfarm equilibrium.

Employment: The agribusiness sector is capable of generating employment both directly (on farm) and indirectly (non-farm) of the abundant rural labour supply. Through job creation, it enhances and expands the market and demand for farm produce, just as the growth of commercial agrifood system in the rural areas is capable of galvanizing economic growth. The efficiency and expansion of post harvest handling, processing and marketing is an important factor in the two edge action of providing food and employment for the people.

Income Generation/Poverty Reduction: The commercial value of agriculture is capable of generating higher incomes. These new income levels are capable of empowering small holder farmers into large holders. The expanded market increases the financial prowess of the inputs suppliers and the market for the processing firms. However sustainability of incomes accruing from agribusiness depends largely on the dynamic link between the farm and the non-farm sectors. When such incomes increase into investible surplus it stimulates growth of the rural non-farm economies and this becomes an important factor in rural poverty alleviation.

Food Security: A successful agribusiness is capable of ensuring availability and entitlement of the people to sufficient food at all times to guarantee healthy life. Agribusiness must ensure food availability (via supply) and encourage entitlement of the people with plenty alternative commodity bundles for the people. (Haruna and Umar 2011). 
Complementarity/Structural Transformation: A strategic link between the farm and nonfarm sectors creates an integrated production structure and a balance between large and small production units. A dynamic agribusiness fuels the growth of the rural nonfarm sector through a number of linkages: while agriculture requires inputs provided by the non-farm enterprises. The rural non-farm sector creates backward integration and forward linkages leading a fast process of structural transformation.

Corporate Social Responsibility: Large processing firms are expected to discharge corporate social responsibility to host communities in addition to providing nutritional needs with quality products. Justifying the mission of establishing Taraku Mills Ltd (an agro process company) in Benue, BOG (2004:11) argues that: “....as a bulwark of agriculture and industry the company meets the farmer at the rural setting, coordinates his agricultural cooperative activities with the provision of some inputs and goes back at harvest time to purchase the proceeds and add value to the farmer's family."

The best scenario for rural development would be when the majority poor have achieved a shift from those conditions considered unsatisfactory to better standards of worth and sustenance. At this time agribusiness could have engendered wider availability of life fundamentals and given the opportunities generated by agribusiness (jobs, etc) the people would have had the impact of cumulative spirals (economically improved) for freedom from servitude capable of fending for themselves without necessarily depending on government.

\section{1. Constraints of Agribusiness in Nigeria}

Marchet et al (2001), Nwangola (2006) Kachru (2007) have attributed endogenous constraints of agribusiness to include low capacity utilization, inadequate working capital, poor policy articulation etc.

(1) Poor Policy Articulation: Improper policy articulation encompasses poor support, policy uncertainties/inconsistencies or failure of agricultural policy results from poor institutional arrangements. This problem ranks third in the rating of agribusiness constraints. Idachaba (2000) argues that there has not been a separate policy articulation for agribusiness except for the brief objectives stated in the 1988 Agricultural Policy for Nigeria a document for agricultural commodity processing. These have amounted to unpredictable government activities

(2) Inadequate Working Capital: This includes shortage of funds raw materials and labour force. In a survey of agro-industrial in Nigeria, Marchet et al (2001) argue that the problem of finance ranks first thereby compounding other problems. Without the requisites capital base, agribusiness cannot flourish nor could it engender economic development. Lack of credit incentives has compounded this problem.

(3) Lack of Appropriate Technology: Using either too obsolete or sophisticated technology tends to frustrate the linkage for lack of know-how and cost of maintenance. Where technology happens to be too advanced for the indigenous labour force, it renders the workforce useless while high energy consuming technology truncates production due to huge cost of fuels.

(4) Inadequate Infrastructure: The state of infrastructure including power, water supply, communication and communal infrastructure like warehouses (stores) drying units, testing labs and treatment plants to a great extent influence the growth of agribusiness. 
Marchet et al (2001) argues that the problem of infrastructure is $2 \frac{1}{2}$ times "worse than the next biggest problem - finance"

(5) Farm - level Constraints: The subsistent small holder production is no hegemonic production frontiers added to the geographical dispersal of farmers constitutes a high cost of bulking. With poor incentives and vagaries or unpredictable state policies the farm component of agribusiness faces seasonality crises that create more uncertainties for the non-farm sector.

\section{CONCLUSION}

The agricultural sector is the highest employer of the rural labour force. Improving the commercial value of agriculture would certainly culminate into a serious agrarian change that would impact on the greater number of people and the rural sector. Agribusiness is said to be a veritable tool for rural development because the farm-non-farm linkage would actually create employment, income, poverty reduction, complementarity etc.

\section{SUGGESTIONS}

(1) Robust Political Will: Government should provide all incentives towards private sector driven agribusiness. Where government is considered a bad business manager due to policy summersaults, she should withdraw but provide the requisite incentives (credit) and level playing ground for agribusiness to flourish. Encouraging farm agribusiness linkages remains the important growth feature of the rural Nigeria. Consequently, provision of rural roads, electricity, and storage facilities is vital in this regard.

(2) Developing a sound Ideology: A sound ideological guide should be introduced to mainstream the unorganized nature of the rural farming communities into coordinated cooperatives in the manner of the Soviet's "AGROGOROD", Chinese "COMMUNES" and Israeli "AGRINDUS". Introduction of farming communities in Nigeria with effective cooperatives is a sure way out.

(3) Proper Policy Framework: Government should formulate a crystal clear policy for the development of agribusiness in Nigeria that should create consistency for those involved in this sector. Such a framework would be considered having the rural man at the centre of its strategy since it would create assurance for a greater number of people. A proper policy articulation should equilibrate agricultural policies with its politics from which the framework will be used as a means of mobilizing resources for national integration and development.

(4) Improving Crop Marketing: The role of agribusiness firms in reducing transaction bottlenecks via direct purchase from farmers is a considerable advantage to both the farm and non-farm components. This strategy of direct sourcing will make industries assist farmers and provide a sure market for their crops. This way they can identify, farms, supply inputs and meet them at the rural setting to buy what is produced.

(5) Availability of adequate working capital: What agribusiness needs to flourish simply include; adequate physical capital: machinery manpower; biological capital: improved seeds, fertilizers herbicides pesticides etc and circulatory capital: funds to be used to 
finance their operations and general overheads. These can be acquired from available credit incentives provided by the state and other financial bodies. For human capital development, agribusiness entrepreneurial training becomes indispensible

\section{References}

[1] Anyanwu J. C. et al (1987). The Structure of the Nigerian Economy, (1960 - 1997). Onisha Nigeria. Joanee Educational Pub. Ltd.

[2] Behnassi M. Draggan S., Yaya S. (2011). (eds) Global Food Insecurity: Rethinking Agricultural and Rural Development Paradigm and Policy. London: Spingewer Publishers.

[3] BOD (2004). Briefs and Proposals for Re-engineering and Revitalization of the Operations of Taraku Mills Ltd, September..

[4] Da'silva C. et al (2009). Agro-Industries for Development U.K. CAB International MPG Book Group.

[5] Dike E. (1991). Economic Transformation in Nigeria: Growth, Accumulation and Technology. Zaria, Nigeria. ABU Press

[6] Dunmoye A. (1987). Agricultural and Economic Growth with Special Reference to the Developing Countries: A Survey of Relevant Theories in Oculi, O. (1987) (ed) Nigerian Alternatives. Zaria, Nigeria. ABU University Press.

[7] Ega L.A., Atala T. K, Baba J. M. (1987). (eds) Rural Development Policies in Nigeria. The Proceedings of the Fourth National Conference of the Nigerian Rural Sociological Association Held at the Kongo Conference Hotel, Ahmadu Bello University, Zaria from May $17^{\text {th }}-20^{\text {th }}, 1987$.

[8] Ekong E. E. (1988). Rural Sociology: An introduction and analysis of Rural Nigeria. Ibadan: Jumak Publishers Limited.

[9] Harris W., Heyer J. (2010). (eds), The Comparative Political Economy of Development. New York: Routledge Pub.

[10] Ijere M. O. (1992). Leading issues in Rural Development. Enugu Nigeria. Acena Publishers.

[11] Jir M. M. (2005). “Agriculture and Integrated Rural Development” in Akeredolu-Ale E.O. (1995) (ed). Integrated rural development in Nigeria: policy issues and options. Ibadan: Spectrum Books Ltd.

[12] Lele U. (1975). The Design of Rural Development Lessons from Africa. Balmore: Holt Rinbert.

[13] Mabogunje A. L. (1981). The Development Process: A Spatial Perspective. Unpublished Ph.D Thesis. Ibadan: University Press.

[14] Meir G. M. (1976) Leading issues in Economic Development. New York Oxford University Press.

[15] Olayida S. O., Heady, E. O. (1982). Agricultural Production Economics. Ibadan Nigeria. Ibadan Uni Press. 
[16] Olayide S. O., Ogunfowora, O. Essang, S.M., Idaachab,S.M (1981). Elements of Rural Economics. Ibadan University Press Publishing House.

[17] Onimode B. (1985). An Introduction to Marxist Political Economy. London Zed Books Ltd.

[18] Todaro M. P., Smith S. C. (2011). Economic Development. India, Pearson Education Ltd.

[19] Ukwu J. U. (1995) “A Critical review of Rural Development Strategy, Policies and Programmes in Nigeria" in Akeredolu-Ale E.O. (1995), (ed). Integrated Rural development in Nigeria: Policy Issues and Options. Nigeria, Spectrum Books Ltd. 